\title{
Masculinities in World Religions. Some Introductory Remarks
}

\section{Daniel Gerster / Michael Krüggeler}

The relationship between religion and masculinity ${ }^{\mathrm{I}}$ has increasingly become the subject of public debates in recent years. If, for example, people in a German pedestrian zone were asked whether they saw a connection between the self-image and behaviour of men and their religious affiliation, a majority would, after a brief moment of reflection, probably answer the question in the affirmative, and then point to the demeanour of young Muslim men. Indeed, criticism of Islam, and of what many perceive as its unenlightened and potentially violent idea of masculinity, is - at least in Western societies, and in Germany not least because of the events in Cologne on New Year's Eve 2015/2016 $6^{2}$ at the centre of public controversy surrounding religion and masculinity. In contrast, other issues to do with this subject - such as the derogatory statements made by some evangelical Christians about the right of women to have an abortion or about same-sex marriages, and the vehement adherence of the Catholic Church to celibacy - often take a back seat in public debates.

But precisely the discussions about the events in Cologne on New Year's Eve also make clear that no simple connection can be established - despite the repeated claims made with regard to Islam not only by German politicians, ${ }^{3}$ but also recently by the US President Donald Trump 4 - between the normative stipulations of a religion and the behaviour of its (male) representatives. Rather than monocausal explanations, we should investigate instead the complexity of the relationship between religion and masculinity by, for

I We use the singular of both terms 'religion' and 'masculinity' throughout, although we are of course aware of the actual plurality of both. The same applies to different religions such as 'Islam' and 'Christianity'.

2 The events in Cologne on New Year's Eve are still the subject of fierce and emotional debate, in the public as well as in the academic sphere. For more details on the discussion, see Kurz, I2I, in this volume.

3 See, for example, the statements made by the CDU politicians Kristina Schröder and Julia Klöckner in: Christian Schwerdtfeger/Eva Quadbeck: 90 Strafanzeigen wegen Sex-Attacken - Kölns OB rät Frauen zu anderem Verhalten [90 Criminal Charges for Sex Attacks - Cologne's Mayor Advises Women to Behave Differently]. In: Rheinische Post, 06/0I/20I6, Ar; and Ulf Poschardt (in interview with Julia Klöckner): Wir haben zu lange nur zugeschaut [We Have Stood By and Watched For Too Long]. In: Die Welt, 06/0I/20I6, 5 .

4 See, for example, Peter Baker/Eileen Sullivan: Trump Sets Off Furor in Sharing Extremist Videos. In: New York Times, 30/1I/2017, AI. 
example, locating the self-image and behaviour of men within the multilayered context of ethnic and social origin, of age, sexual orientation, and personal religiosity, as well as by analyzing the historical development and internal plurality of a religion such as Islam. ${ }^{5}$

How multi-layered the mutual relationship really is between religion and masculinity becomes even clearer when we shift our focus from the current situation in Germany and expand our perspective both historically and geographically. A look into the past of European Christianity already suffices to prove the historical contingency of the position of men in and to religion on the one hand, and of religious ideas and practices of masculinity on the other. It is of course true that the Christian religion constituted and stabilized for centuries (and it still does to a large extent today) the social, political and economic dominance of men - theologically, by deriving the gender polarity in society from a divine order; dogmatically, by justifying the prominent position of men in church and society. Not without reason was and is God often understood and depicted as a 'man'. But there are also counterexamples in history that question male dominance. Thus, a feminization of religion has been repeatedly attested for the $19^{\text {th }}$ century, ${ }^{6}$ and Pope John Paul I said in I978 that "God is our father; even more, he is our mother". ${ }^{7}$

The image that we have chosen for our book cover also exemplifies the historical change that the relationship between religion and masculinity constantly undergoes. ${ }^{8}$ Lucas Cranach the Elder's depiction of Adam can of course be interpreted as a classic topos of a male dominance promoted by Christianity, and its reproduction on our cover page therefore criticized as continuing hegemonic and Eurocentric ideas of masculinity. 9 On the other hand, though, we could also take a historical perspective and point to the fact that the image of God in 'man' depicted in the painting was challenged at the

5 Thus, in connection with the events in Cologne, the Frankfurt anthropologist Susanne Schröter rightly called for a nuanced approach to Muslim men, and accused the discipline of gender studies of lacking practical relevance. See, for example, Thomas Thiel (in interview with Susanne Schröter): Wie viel Islam steckt im sexuellen Übergriff? [How Much Islam is there in Sexual Assault?], in: Frankfurter Allgemeine Zeitung, I8/0I/20I6, II.

6 On the state of the discussion, see, for example, Pasture et al. (eds) 20I2. See also in this volume the comments by Werner, 39-63. On the opposite tendencies of re-masculinization, see, for example, Blaschke 201 .

7 John Paul I, Angelus Address, Io/09/1978, URL: http://w2.vatican.va/content/john-paul-i /en/angelus/documents/hf_jp-i_ang_I009I978.html [Accessed: 28/02/20I8].

8 Lucas Cranach, Adamo (Uffizi, Inv. I890, n. I459). The painting from I528 is in the Uffizi Gallery in Florence. We are very grateful to the Gallery for allowing us to reproduce it here.

9 On this, see, for example, Reeser 20I0, 22, who refers here for the only time in his entire book on masculinity to the connection between masculinity and religion. 
latest in the wake of the Enlightenment, and that the Renaissance aesthetics used by Cranach no longer correspond to today's ideals of masculinity. ${ }^{\text {IO }}$

Besides historical depth, global breadth can also help us to become aware of the complexity of the relationship between religion and masculinity. What we notice at once is the plurality and intricacy of the phenomenon of 'religion' itself."I This volume uses the not uncontested notion of 'world religions' to make clear that its contributions are grouped around the religious traditions considered central in Western (everyday) discourse: namely, Christianity, Islam, Judaism, as well as Buddhism and Hinduism. ${ }^{\text {I2 }}$ Sociological investigations that take a global perspective can provide initial evidence of similarities and differences between different religious traditions and masculinities. According to such investigations, women worldwide are fundamentally more religious than men, with many other factors such as age, level of education, and social position also playing an important role in individual religiosity. However, there is a clear difference when it comes to attendance at religious services: men attend more frequently in predominantly Muslim countries, while the majority of those attending in predominantly Christian countries are women. ${ }^{\mathrm{I}} 3$

Given the complexity of the situation that we have sketched, our view is that research on the relationship between religion and masculinity in the sociology of religion should in essence focus on three questions. First, from a theoretical point of view, it is important to gain fundamental insights into the

Io These accusations can be further invalidated by pointing to the question mark very deliberately used in the title of the volume God's Own Gender? More exciting than the frequently asked questions of whether God has a (male) gender, and whether 'man' is due social privileges on account of the biblical story of creation, is in any case the theological question of whether the Genesis text does in fact not consider (long before Judith Butler) some kind of deconstruction of gender identity. For, according to tradition, Adam and Eve are indeed already created by God with physical gender attributes, but they recognize both their gender affiliation and their actual gender identity ('sex') only after their expulsion from paradise.

II On the question of religious plurality, see most recently Willems et al. (eds) 20I6. For an overarching discussion of the concept of religion, see, for example, Feil 1986-2007; Id. (ed.) 2000; Despland/Vallée (eds) I992; De Vries (ed.) 2008; Hermann 20I5, 77-I40. For fundamental criticism of 'religion' as a Eurocentric term, see Asad 1993, esp. 27-53; McCutcheon 1997; Fitzgerald 2000; Dubuisson 2003. For an overview of the debate in German, see Pollack 2018.

I2 On discussions surrounding the notion of 'world religion(s)', Masuzawa 2005 is still relevant. For suggestions on further discussion, see Hermann 2015, I70/17I. The choice of religious traditions in our volume is based on purely pragmatic reasons, and is not to be understood as a fundamental restriction of the issue to the religions that we deal with.

13 See PEW Research Center, The Gender Gap in Religion Around the World, 22/03/20I6, URL: http://www.pewforum.org/20I6/03/22/the-gender-gap-in-religion-aro und-the-world/ [Accessed: 28/02/20I8]. See also on the relationship between religion and gender in international comparison, Pollack/Rosta 20I7, esp. 39I-4II. 
relationship between (world) religions and their normative stipulations (for example, in sacred texts or sermons) on the one hand, and the social position of men, as well as how they are talked about and how they act, on the other. It is particularly important in this context to address the reciprocity of the relationship between a religious tradition and the men involved in it, by highlighting how male dominance is constituted and consolidated, but also delegitimized. ${ }^{14}$ At a second level, it is also important to present the relationship between a specific religious tradition and different ideas and practices of being a man in its historical contingency, and to demonstrate its entanglements with other factors such as social class, age and sexuality - that is, its 'intersectionality'. ${ }^{15}$ Such an investigation requires work on actual historical case studies that can enable the researcher to describe changes in the relationship. At the same time, such studies make it possible to compare with the present situation, with the global measurement of the present being the third task of research on religion and masculinity. Here, too, it is necessary first and foremost to have sound empirical studies on the concepts and practices of masculinity in different religious traditions in different regional contexts. These studies can then be the basis for further studies on the similarities and differences between religions; ideally, they can also be used to verify theoretical assumptions.

The aim of this volume is to bring together the different answers that various disciplines, such as sociology, theology, history, and Islamic and religious studies, have given to the three questions, and to compare the different findings provided by historical and global case studies on the relationship between religion and masculinity. Ultimately, such a project can only serve as a first attempt, also because most of the contributions focus not only on one world religion, but mostly also on specific historical and geographical constellations. The contributions arose from a conference organized jointly by the Center for Religion and Modernity, the Cluster of Excellence 'Religion and Politics', and the Centre for Islamic Theology at the Westfälische Wilhelms-Universität Münster in November 20I6. The case studies have been supplemented for this volume by more comprehensive overviews of the relationship between different world religions and masculinities. Before presenting the individual contributions (3), we will provide in the following a brief overview of the state of research in general and in specific disciplines (I). We will then make a few brief reflections on theoretical research questions and perspectives (2). Finally, we will identify current gaps in the research, and provide an outlook on future fields of research (4).

I4 On this, see also section 2 of this introduction.

I5 On this issue, see, for example, Lenz 2010 and Hearn $201 \mathrm{I}$. 


\section{State of Research}

What appears obvious is that, through their sacred scriptures and normative texts, their commandments and prescriptions on how to live, the nature of their organization, and their practices and rites, religions have always had a significant impact on how people think about and practise gender as a core concept of the social order. ${ }^{16}$ At the same time, and as we have already indicated above, we can point to numerous examples in history of how people have used religion to constitute and legitimize male dominance in social, political and economic spheres. Although both connections have long been known, intensive academic research into the relationship between religion and masculinity has only really taken place over the last three to four decades. ${ }^{17}$ But the fact remains of course that some disciplines - especially anthropology and ethnology, but also sociology and the theologies - have a longer tradition of dealing with the relationship between religion and gender. For example, in his work The Elementary Forms of the Religious Life, which was published in the early $20^{\text {th }}$ century, Émile Durkheim not only portrayed the separation of the 'sexes' as a central aspect of the social order, but also traced this separation back to religion as a moral sanctioning power. ${ }^{18}$ However, this example also makes clear the problems that usually beset works published on the subject up until and into the I970s. On the one hand, since they absorb traditional gender ideas into their research without questioning or using them critically, they merely perpetuate such ideas, and mostly in the form of binary, and often natural, gender roles. On the other, many focus solely on deconstructing the gender of 'woman' in its religious and social contexts, something to which the women's movement of the I96os also contributed much with its demands. ${ }^{19}$

I6 Case studies on the relationship between religion and gender from different eras and regions of the world have been brought together recently in a Special Issue of Gender and History 25 (3) (2013). For its underlying theoretical reflections, see De Groot/Sue 2013.

17 Masculinities, also in relation to religion, were of course an issue in previous centuries, too; see Kucklick 2008. However, the discourse has become more intense - and perhaps 'noisier' - during the last few decades. Reference to a caesura in gender studies can already be found in the mid-I980s. Thus, Scott 1986, I066, argues that "gender as an analytic category has emerged only in the late twentieth century".

I8 See Durkheim 2008 (orig. I9I2).

I9 Regarding the criticism, see King 1995. Examples of both 'problems' can be found in more recent publications, too: Kippenberg/von Stuckrad (eds) 2003, for example, stresses the importance of binary 'gender roles', while Stollberg-Rilinger (ed.) 20I4, as well as the latest volume of the Interdisciplinary Journal for Religion and Transformation on 'Religion, Transformation and Gender' (2017), focus on deconstructing women under the overall label of 'gender'. On this discussion, see also Krondorfer/Hunt 2012 and Krondorfer 2016. 
We can in fact not identify a genuine research interest in the complex relationship between religion and masculinity until the early I980s. The change was due among other things to the fact that positivistic ideas of gender were increasingly questioned in this decade in favour of a constructive and fluent understanding, which made calls for a gender studies that went beyond previous definitions louder in numerous disciplines. ${ }^{20}$ Religious studies and the theologies also began to reflect once more in this context on 'man', who as an "unmarked" ${ }^{2 I}$ gender had hitherto largely avoided academic (self-)reflection. Pioneering here in the Anglo-Saxon world were the studies of so-called 'gay theological studies', such as John Boswell's Christianity, Social Tolerance, and Homosexuality. ${ }^{22}$ At the end of the 1980s, various academics in the US finally joined forces to form research networks in order to investigate more closely the relationship between religion and masculinity. The findings and publications arising from these networks mean that '(critical) men's studies in religion' has been an independent field of research since the mid-I99os. Or at least that is the conclusion reached by Björn Krondorfer, who as one of the most renowned researchers in this field has his say at the end of this volume. ${ }^{23}$ The number of academic studies on the relationship between religion and masculinity has grown steadily since then, first in the US, but also in the last decade beyond the US. ${ }^{24}$ The fact that many recently published handbooks have taken up the issue may serve as further evidence that it has generally become of increasing academic relevance. ${ }^{25}$

This brief outline of work that religious studies and denominationally oriented research have produced on the relationship between religion and masculinity in recent decades already shows that the centre of interest has been Christianity and its different traditions and history. Only since the mid-I990s has there been an increasing number of studies on other religious

20 On this, see, for example, the contributions in the discipline of history of Scott 1986 and Bock 1988. Also important to the debate are of course the works of Foucault I976-I984 and Butler 1990. See below for more details. On the formation of the discourse surrounding the construction of masculinity, see Brod $201 \mathrm{I}$.

2I Reeser 20I0, 8. Reeser's reflections on "marked/unmarked" pertain to: Barthes 1967 (orig. 1964), 76/77.

22 See Boswell 1980. An overview of the current state of masculinity studies has been made available recently in German: Reeser 20I6. The wide scope of Anglo-Saxon research in the field is summarized in Connell et al. (eds) 2004 and Flood et al. (eds) 2007. For the German-speaking area, see recently Horlacher et al. (eds) 2016.

23 For the history of the research field, see Krondorfer's article in this volume, 283-300. See also Krondorfer/Culbertson 2005; Krondorfer 2009; Krondorfer/Hunt 2012 and Krondorfer 2016.

24 Most notable in this regard was the research project on the issue of Christian Manliness - A Paradox of Modernity conducted at the University of Lund until 20IO. For the results, see Werner (ed.) 20II.

25 See, for example, Hock 2002; Heller 2003; 20I0; Höpflinger et al. (eds) 2008 and Horlacher et al. (eds) 2016. 
traditions, first on Judaism, and in recent years on Islam, Buddhism and Hinduism. It quickly becomes clear that the various studies each have their own priorities in terms of thematic and historical focus, priorities that are usually derived from their own traditions and from the history of the religion with which they are concerned. For example, studies on the Christian religion initially focused on central male roles such as that of the priest or housefather, and examined the link between ideals of masculinity, body and power in the modern period. It is only in recent years that researchers have widened their scope, now focusing not only on the entire time span from antiquity to the present day, but also on Christian masculinities outside the Western cultural circle. ${ }^{26}$ The first studies on the relationship between Islam and masculinity emerged at around the same time, with a large number focusing primarily on (homo-)sexuality. ${ }^{27}$ By contrast, studies on Judaism have so far addressed mainly the relationship between religion and the male body, with The Rise of Heterosexuality and the Invention of the Jewish Man by the American philosopher of religion Daniel Boyarin leading the way. Boyarin's text continues to serve as the basis for further studies that detail how the ideal and practice of Jewish masculinity have changed from biblical times to the present day. ${ }^{28}$ In contrast, our knowledge of the interplay between Asian religious cultures and masculinity has been limited. However, works such as that of John Powers indicate that it is also important to put simplified ideas of gentle and peaceful Buddhist and Hindu 'men' to the test. ${ }^{29}$ All in all, our knowledge of the relationship between religion and masculinity has increased significantly in recent decades, although studies comparing religions have been lacking until now; it is precisely this gap that we wish to fill here.

Regardless of the religious tradition that they focus upon, or the time and place that they select, recent studies on the relationship between religion and masculinity are united in the fact that their research questions are concerned in essence with a handful of issues - namely, with sexuality and the body,

26 See, for example, Dinges 1998 and 2005 . For the $19^{\text {th }}$ and $20^{\text {th }}$ century, see Werner (ed.) 20II and Pasture et al. (eds) 20I2. For African Christianities, see, for example, Klinken 2013. The relationship between religion, gender and secularization has also been studied recently; see, for example, Brown $201 \mathrm{I}$ and Borutta 2014.

27 See, for example, Ouzgane 2006; Kugle 20I0; Kugle/Hunt 2012 and De Sondy 2014. The relationship between Islam and homosexuality caught the attention of gender studies very early; see, for example, Scott 1986, I07I: "In medieval Islamic political theory, the symbols of political power alluded most often to sex between man and boy". On the orientalist bias of such research on Islam and (homo-)sexuality, see Kurz, II7/II8, in this volume.

28 See, for example, Boyarin I997; Brod/Zevit 20I0; Creanga 20I0; Baader et al. (eds) 2012.

29 On Buddhism in South Asia, see, for example, Soucy 1999 and Powers 2009. On Hinduism, see Gupta 20II. On South Asian masculinities in general, see Chopra et al. (eds) 2004 . 
with violence, hierarchy and power. These issues have also been central for quite some time in masculinity studies in general, ${ }^{30}$ while other concepts such as that of (binary) gender roles, and issues such as that of patriarchy, have taken a back seat. ${ }^{3}$ The new themes are based on various theoretical approaches that - again since the I980s - have shaped the overall academic debate on gender issues. These include, first of all, the approach introduced by Michel Foucault in his three-volume work on the history of sexuality that investigates the relationship between power and sexuality through discursive patterns. ${ }^{32}$ This has proven an effective interpretative tool in the decades since Foucault's early death, and not only in masculinity studies. Just as influential in general discussions on gender has been Judith Butler's idea of the performativity of 'gender' and 'sex', 33 although masculinity studies has so far tended to give the idea only limited attention. 34 On the other hand, the work of Pierre Bourdieu, who in Masculine Domination employs his theory of habitus to explain the continuing dominance of men, has had great resonance. 35 His remarks connect up with the ideas of Raewyn Connell, whose concept of hegemonic masculinity has been perhaps the decisive theoretical instrument in masculinity studies over the past few decades. ${ }^{36}$ We will now systematically examine the different theories in terms of what they can offer to research on the relationship between religion and masculinity.

\section{Theoretical Reflections}

If we wish to place the theoretical conceptualization of the relationship between religion and masculinity in the current discussions on gender, then it is necessary first of all to focus on an obvious, but perhaps thereby frequently

30 See Meuser 20I6, 220-230.

3I The importance of the concept of (binary) gender roles especially in the I950s and I96os is shown, for example, in the research of Talcott Parsons. It lost its dominance in the I980s through the emergence of theories of social construction; see Meuser 20I0, 50-78. Studies on patriarchy long took a central position in feminist research in particular; for an overview, see Cyba 20Io; the issue then enjoyed its heyday in the history of masculinity in the I990s; see Tosh 1994; Mosse 1996; Tosh 1999. Used critically, both concepts remain interesting for future research.

32 See Foucault 1976-1984. Foucault's work was initially intended to comprise six volumes, but was not completed due to his early death. Fragments of the fourth volume have been published recently; see Foucault 2018.

33 See Butler 1990.

34 For example, Butler's idea has found a lasting basis in the history of masculinity in the German-speaking area only in the work of Jürgen Martschukat and Olaf Stieglitz; see, for example, Martschukat/Stieglitz 2008.

35 See Bourdieu I998; cited hereafter in the English translation: Bourdieu 200I.

36 See, for example, Connell 1987; 1995; Connell et al. (eds) 2004. For a global perspective on masculinity, see Connell 2016. 
overlooked, contrast: while the vast majority of (world) religions - including those dealt with in this volume - tend to understand and legitimize through their norms and ideals biological-physical 'sex' as a natural, ontologically given and therefore unquestionable basis of the social gender order, current gender studies has begun to emphasize the social constructedness of all forms of gender, including even the apparent biological distinction between the 'sexes'. Of course, the most far-reaching approach here is represented by the philosopher Judith Butler and her concept of performativity, which ultimately aims to dissolve the distinction between 'sex' and 'gender': "Because there is neither an 'essence' that gender expresses or externalizes nor an objective ideal to which gender aspires; because gender is not a fact, the various acts of gender create the idea of gender, and without those acts, there would be no gender at all". ${ }^{37}$ According to Butler, it is only through the constant repetition of culturally specific semantics and practices that gender - even in its biological-physical dimension - becomes constructed, open to experience, and perceptible. $3^{8}$ Such a performative approach means examining when it comes to the relationship between religion and masculinity the extent to which religious images, prescriptions, ideals, and norms form part of that dense web of texts, regulations, stories, and images that constitute the self-perception and actions of men - as 'men' - in general and especially in a socio-religious context.

Besides Butler's theory of performativity, there are other theoretical approaches in the social sciences that allow us to question fundamentally the ontological claim postulated by religions that there is a natural gender order comprising 'man' and 'woman'. Particularly noteworthy here is the concept of 'discourse', which, mostly following the work of Michel Foucault, has in the course of the turn of the humanities and social sciences to cultural studies received increasing attention since the I980s. In his early work, in which he was concerned above all with emphasizing how knowledge, detached from 'reality', could become an instrument of power, Foucault understood by 'discourse' the unspoken system of rules that prescribes what can be said about a particular issue, how it is said, and who may say it. ${ }^{39}$ Since Foucault himself was rather cautious when it came to the question of how to examine such discourses (which tend today to be called dispositifs, so as also to

37 Butler $1988,522$.

38 On this, see also Butler 1990, which is still essential. For an introduction in German, see Bublitz 2002 and Martschukat/Stieglitz 2008, 2I-27. On the (feminist) discussion of Butler's theory in Germany, see Purtschert 2003.

39 See, for example, Foucault I966 and I969. For an introduction in German, see, for example, Sarasin 20I3. A successful synopsis of the life and work of Michel Foucault is also provided by Eribon $201 \mathrm{I}$. 
include the "unspoken"), $4^{40}$ there have over the years developed a number of very different approaches, each differing according to the discipline in which it is located and its understanding of discourse. It has therefore become the rule in research in cultural studies and the social sciences to investigate "less the things in themselves, and much more the meanings that these things accrue, the meanings that they carry and reproduce, and thus ultimately make tangible in the first place". ${ }^{4}$ Insofar as religion and religions must be regarded in most societies as fundamental and prominent mediators of 'meanings', they can be analyzed as eminent components of discourses: not least in the mediation of meaning for the perception of gender and gender affiliation, for the self-perception of women and men, and for their relationships within actual social practices.

If we wish to see the relationship between religion and masculinity in terms of the most important findings made by gender studies in the social sciences as a whole, we cannot avoid referring also to approaches that emphasize the multiply relational formation of men and masculinities. Being a man is in this context generated among other things in conflict with other genders: with men, under conditions of competition and community, in a homosocial dimension; and with women and femininities, under conditions of demarcation and domination, in a heterosocial dimension. This factor of relational formation, which we can find, albeit with different orientations, in the work of Raewyn Connell and Pierre Bourdieu, ${ }^{42}$ already points to the sheer complexity of positioning masculinities in contemporary and current gender debates. This complexity is increased further if we look at a second feature of relational formation - namely, the linking of masculinities with other categories of social reality. This point of view has been recently highlighted under the heading of 'intersectionality', 43 which argues that the dispositifs of masculinity are tightly bound up in structural categories of class and race, of national or ethnic affiliation, and so on. The social category of religion, which we analyze in this volume, is one of these social features, but in turn it has intricate entanglements with other social categories, too. What has especially come into focus recently here is the question of spatial differences and

40 See Martschukat/Stieglitz 2008, 60. See also Landwehr 2008.

4I Martschukat/Stieglitz 2008, 25 (our translation). On attempts to translate 'discourse analyses' into the German-speaking social sciences and cultural studies, see, for example, Sarasin 2003; Keller 2004; Landwehr 2008.

42 On the competition between different concepts of masculinity, as well as of men and women, see Connell 1987; 1995; Connell. et al. (eds) 2004. On the issue of conflict between men, see especially Bourdieu 200I. On the place of Bourdieu's approach in the general reflections of women's studies and gender studies, see, for example, Fowler 2007; Engler 20I0; Jäger 20I2. For criticism of Bourdieu's concept, see, for example, Krais 20II and Heitzmann 2015.

43 See, for example, Lenz 2010 and Hearn 2011. 
transnational entanglements between masculinities and other social categories.44 This volume also addresses this question by analyzing the connection between religion and masculinity in five different (world) religions. The benefit of such a transnational perspective also lies from a theoretical point of view in helping us to overcome Eurocentric conceptualizations in our analyses of religion and masculinity.

Besides these fundamental reflections, what have also played a role in sociological analyses dealing specifically since the 1980 s with masculinity from a position outside general gender debates are theories that focus primarily on power constellations in gender relations (i.e., from men to women, but also to other men), and that therefore understand and conceptualize the analysis of masculinity as (to echo Pierre Bourdieu) a form of "symbolic domination". 45 The most influential conceptualization of male domination is still the concept of 'hegemonic masculinity' developed by the Australian sociologist Raewyn Connell. As we know, Connell draws for her reflections on Antonio Gramsci's notion of hegemony, thereby denoting a form of domination that is produced not through manifest coercion, but through a commitment to general cultural values as an implicit consent given by the disadvantaged and subordinated..$^{6}$ In the heterosocial dimension of relations between men and women, hegemonic masculinity appears as the symbolic and institutional link between masculinity and authority, a link that, for Connell, should be understood as the main axis of male power, and socially as a structural relationship of domination. In the homosocial dimension among men, hegemonic masculinity appears in relation to other masculinities, which Connell differentiates as "complicit", "subordinate", and "marginalized". Hegemonic masculinity appears overall as a cultural ideal of masculinity that is primarily realized by social elites, but is supported and understood by the overwhelming majority of men as a pattern of orientation. 47

Various contributions in this volume draw on this very concept of hegemonic masculinity to analyze the relationship between religion and

44 See Connell 20I6. For the postcolonial criticism of Eurocentrism and poststructuralist concepts of space and (hybrid) identities, Bhabha 1994 is still essential.

45 The idea of the masculine as symbolic domination is already developed in the 'Prelude' to his work Masculine Domination; see Bourdieu 200I, I-4. Here, Bourdieu speaks of male domination as a form of "symbolic violence". By this he means "a gentle violence, imperceptible and invisible even to its victims, exerted for the most part through the purely symbolic channels of communication and cognition (more precisely, mis-recognition), recognition, or even feeling"; see ibid., I-2. Bourdieu speaks of "symbolic rule" in: Ibid., Preface and 37, 96-IOI.

46 Gramsci's reflections on cultural hegemony and subaltern groups are scattered in the so-called 'prison notebooks'; see, for example, Gramsci 1934. For an introduction, see Buckel/Fischer-Lescano (eds) 2007.

47 Essential here is Connell I995, esp. 67-86 and I85-203. 
masculinity. $4^{8}$ Connell's concept has become virtually a classic topos not only in masculinity studies as a whole, but also in the analysis of masculinity in religious studies and the sociology of religion. In contrast, Bourdieu's concept of a masculine habitus has so far been used less often, although it still plays a role in studies conducted in the social sciences. In the notion of masculine habitus, Bourdieu emphasizes in particular the importance of competition among men for the construction of masculinity, and distinguishes, like Connell, between a homo- and a hetero-social dimension.49 Bourdieu conceives as the basis of the masculine habitus a libido dominandi, "the desire to dominate", ${ }^{\circ}$ which, in his opinion, shapes the actions of the 'man' both towards other men and towards women. According to Bourdieu, the aim of research must be to uncover the different manifestations of masculine domination, as well as the means and ways in which it prevails in society. Bourdieu especially emphasizes in this context the competitive structure and the homosocial character of competition among men, while assigning women a role that is marginal, but not unimportant, for the constitution of masculinity, since women have to ensure that every 'man' rises 'to his own childhood conception of manhood". $5^{1}$ "Manliness, it can be seen, is an eminently relational notion, constructed in front of and for other men and against femininity, in a kind of fear of the female, firstly in oneself". ${ }^{2}$

Thus, if we wish to carry out a systematic social-scientific analysis of the role of religions in constituting and legitimizing masculine dominance, then, to follow Connell and Bourdieu, we should make use both of the differentiation between a homosocial and a heterosocial dimension, and in particular of the aspect of competition among men as the generating principle of the masculine habitus that Bourdieu highlights. On that basis, future studies could - and should - systematically investigate the constituting and legitimating role of religions within fields of serious competition among men, 53 as well as analyze the corresponding images and roles of women in a specifically reli-

48 The contributions in this volume of Krämer, Kurz, De Sondy, Kosman, Young, Powers, Syed and Krondorfer refer explicitly or implicitly to Connell.

49 See Bourdieu 200I. Bourdieu's concept, which was published in German for the first time in 2005 under the title Die männliche Herrschaft, was taken up in Germanspeaking sociology especially by Michael Meuser, who further developed it under the notion of the 'masculine gender habitus'; see, for example, Meuser 2010 (orig. 1998) and 2016.

50 Bourdieu 200I, 80.

5I According to Bourdieu 200I, 69, who refers to the narration in Virginia Woolf's To the Lighthouse. It is precisely his concentration on the homosocial relations of men, as well as his pessimistic attitude as to whether a change in circumstances is possible, that has earned Bourdieu repeated criticism; see, for example, Krais $201 \mathrm{I}$ and Heitzmann 2015 .

52 Bourdieu 200I, 53.

53 See ibid., 47. 
gious context. At the same time, such a dual research perspective can connect to the multiply relational formation of masculinity in a complexly structured gender context, as described above.

As part of a systematic theorization in sociology (and the sociology of religion) of the relationship between religion and masculinity, we should also reflect on the theoretical approaches in gender and masculinity studies mentioned above against the background of the general demand made to overcome the dichotomy between structure and action. 54 This dichotomy is located in the opposition between structurally operating discourses (Foucault) or performative acts (Butler) on the one hand, and the social action of people in everyday life on the other. It is not easy to integrate the two, but the attempt should at least be made. To do so, we could on the one hand understand religions "as the sedimented and persistent effects of perceptual patterns and power structures" that "are embedded in the very body of the human being", and as belonging to "historically specific cultural configurations" 55 that express an overall social structure in discourses, dispositifs, and habitus formations. Religions, since they are part of such pre-reflexive and incontestable systems, determine, shape and carry social practice and social action..$^{6}$ On the other hand, though, religions should certainly not be understood as static cultural structures; rather, they prove to be not only mutable, but also often as inspiring and fostering a social practice that is capable of reflecting on, questioning and changing established social systems. This also applies to the relationship between religion and masculinity, which in this respect can and should be understood as flexible and mutable forms of social practice that have a retroactive effect on the social structure. Translating these connections and attributions into theoretically sophisticated sociological concepts, and using them productively in complex research approaches, may well be a major challenge faced by future studies that analyze the relationship between religion and masculinity. 57

54 The sociological discussion on the relationship between structure and action, society and individual, is ultimately as old as the discipline itself. Reflections on the relationship can be found in the work of classic figures such as Karl Marx, John Stuart Mill, and Max Weber, as well as in that of modern theoreticians such as Talcott Parsons, Niklas Luhmann, Michel Foucault, and Pierre Bourdieu. An overview of the discussion, as well as a broad attempt to dissolve the dichotomy, can still be found in more recent literature: for example, Giddens 1984. The issue is also addressed with regard to questions of masculinities in Reeser 20I0, 24-27; see also the further references to the issue there: Ibid., 52-54.

55 Martschukat/Stieglitz 2008, 53 (our translation).

56 Still essential to the issue of social practice is Bourdieu 1990.

57 On this, see also Meuser 20I6, 222: "The question of how the relationship between structure and agency can be defined in such a way that we do not fall prey either to a structurally deterministic fatalism or to a creative optimism that omits structure has 
If it is necessary to reflect on the relationship between religion and masculinity always also with regard to a changing and disruptive social practice that questions established social order, then two further factors come into play: namely, the diagnosis of a crisis (of masculinity), as well as the factor of historical change (with regard to masculinity in general, and to the relationship between religion and masculinity in particular). Both aspects have already been investigated a number of times in masculinity studies. It has now been noticed retrospectively that the diagnosis of a 'crisis of masculinity' to describe current shifts in images of masculinity, in gender relations, and in how different groups of men perceive themselves and others is a constantly recurring topos in discourses of masculinity, especially in those of modern societies..$^{8}$ However, it is precisely this recurring factor that has led the literature to pose critical questions concerning the use of the semantics of crisis. Central to this criticism is the insight that talking about a crisis presupposes that there is an objectifiable framework of masculinity that has fallen into crisis. 59 But if, in line with the theoretical approaches outlined above, we are to understand gender and masculinity as performatively and discursively constructed social entities, then such an essential masculinity cannot exist. If, moreover, we follow Bourdieu and see the masculine habitus as a solidified structural category that tends to block an intentional will to change, then the regular proclamation of a crisis appears in a different light. It seems obvious that talk of crisis can also help to reinforce and stabilize the claim to its dominant position of a certain form of masculinity - generally, that of the white, Christian and heterosexual middle class. ${ }^{60}$

However, if we use the concept "as a heuristic instrument", ${ }^{61}$ then the topos of a crisis of masculinity can also yield insights. First of all, we would see the concept of crisis as indicating those historical moments and phases in which there are repeated shifts in the gender hierarchy, and in which social

not yet found convincing answers, and not only in masculinity studies" (our translation).

58 Research was early to address a 'crisis of masculinity'; see Connell I987, I58-I66; Kimmel 1987b; Tosh 1994, I93; Mosse 1996, 77-106. An overview of the issue is provided by Robinson 2007. On the relatively well-researched 'crisis' in around I900, see, for example, Brunotte/Herrn (eds) 2007 and Schuhen 2014.

59 The various arguments have been recently summarized systematically by Roberts 20I6. On this, see also the reflections in the introduction by Opitz-Belakhal/Hämmerle (eds) 2008 and Martschukat/Stieglitz 2008, 64-73. On the productiveness of 'crises' in (hegemonic) masculinity, see Krämer/Mackert 2010.

60 This idea also appeared early on in the research; see, for example, Kimmel I987b. The subtitle of the German translation of Connell's work Masculinities also refers to the connection between "construction and crisis of masculinities"; see Connell I999. How hegemonic claims are enforced with the help of the discourse of crisis is shown in this volume by the contribution of Krämer, 65-84.

6I Martschukat/Stieglitz 2008, 69 (our translation). On the following, see ibid., 64-73. 
upheavals can indicate the fragility of seemingly stable perceptions of identity and social practices. In other words, using the crisis metaphor points to the fundamental insight that normative dispositifs, as well as social practices of masculinity, are historically mutable, ${ }^{62}$ and that we should understand the connection between religion and masculinity as being permanently involved in such changes. Thus, research on religion and masculinity should always adopt a perspective of historical change, within which religion and religions would be identified in concrete historiographical constellations as active or reactive social entities with regard to the transformation of the gender hierarchy. Considering the internal perspective of religions could also be used as an opportunity to think from the margins of the gender hierarchy and to focus attention on analyzing different religious movements of socially marginalized and subordinate groups of men (and women).

Finally, we should address one particular aspect of the perception of the crisis of masculinity, and especially in its connection with religion. This aspect also emerges as a suggestion from the transnational context of the studies in this volume, which show that, in some religions (for example, in Judaism, but also in Hindu and Buddhist traditions in South Asia), women represent a challenge and a danger to men, since sexual-bodily contact between men and women during menstruation or the postpartum period appears to threaten masculinity through pollution. In the extension of an accompanying male anxiety, social contact with women is often interpreted as posing an essential threat to stable masculinity, insofar as women are assigned the capacity to weaken bodily and/or spiritual male powers, or to transform actual masculinity into a kind of femininity. ${ }^{63}$ This results in fear of a 'fluid masculinity', one in which male strengths and male dominance are diminished, and in which, in the worst case, men are transformed into women. ${ }^{64}$

Research in the social sciences on the relationship between religion and masculinity can build in this context on a number of studies already carried out. For example, Mary Douglas has viewed the social assignment of 'purity/ impurity' as a fundamental means to maintain social hierarchy. ${ }^{65}$ In addition,

62 The historical contingency and mutability of masculinity have been the focus of attention in masculinity studies since its beginnings; see, for example, Connell 1987 , I43-I66; Kimmel I987a and I996; Bosse/King (eds) 2000.

63 On this, see the articles on South Asia by Young, Syed and Powers in this volume.

64 On the fluidity of masculinity, see most recently, for example, the introduction by Krondorfer/Hunt 2012; see also Reeser 2010, I06-I09; De Groot/Sue 2013; Reeser 20I6, 38; Krondorfer 20I4; 20I6. Referring to Walz 2008, I6, the latter describes the goal as being to "confront normative paradigms with 'fluid, unruly and unfamiliar ideas of gender" (our translation).

65 Both the article by Serinity Young in this volume, 22I-243, and the contribution by Wohlrab-Sahr/Rosenstock 2000, note 5, refer in this context to the essential study by Mary Douglas 1966. 
Monika Wohlrab-Sahr and Julika Rosenstock have understood the code of 'purity/impurity' as a 'second coding' of the religious system, a system in which on the one hand religion is linked with morality to enable people to experience transcendence in immanence, and on the other the interests of religions in maintaining social hierarchy become manifest through a normative conceptualization of gender relations. ${ }^{66}$ The relevance that these insights and conceptualizations have for analyzing the relationships between religion and masculinity should be immediately obvious. In particular, studies comparing religions would need in the future to investigate further whether and to what extent ideas of a fluid masculinity play a role in different religions, at different times, and in different social contexts, and what significance must be attributed to the "fear of the female" 67 in generating the masculine habitus in religious contexts, too.

\section{Contributions to this Volume}

This volume brings together studies on the relationship between different (world) religions and masculinities. Its four sections focus on those religious traditions that are currently the most widespread and socially influential across the globe: Christianity, Islam, Judaism, and Buddhism and Hinduism. Each section opens with an overview that reflects conceptually on the relationship of the specific world religion to masculinity, and presents the current state of research. This overview is followed by one or two case studies that examine the relationship between the specific religious tradition and masculinity from a historical and geographical perspective. The chapters cannot cover the relationship between religion and masculinity on a global scale, and nor can they deal with the relationship throughout history. Rather, they focus on selected historical and geographical constellations that have been central to research in recent years: the relationship between Western Christianity and masculinity in the $19^{\text {th }}$ and $20^{\text {th }}$ century; ideas and practices of sexuality and homosexuality in premodern and modern Islamic traditions; concepts and practices of Jewish masculinity and sexuality in talmudic and medieval literature; and Buddhist images and Hindu constructions of masculinity in South Asian religious traditions. References to further research - for example, on masculinities in the premodern Christian period - can be found both in the chapters and in this introduction. It is also pertinent to note that the chapters are written from the perspective of different disciplines, and

66 See Wohlrab-Sahr/Rosenstock 2000.

67 Bourdieu 200I, 53. 
they therefore relate to the theoretical concepts and reflections presented to very different degrees.

As noted, the contributions on Christianity focus in their approach on the development of the Christian religion in Western societies since the $19^{\text {th }}$ century. Such a focus is already evident in the overview provided by Yvonne Maria Werner, who aims in her contribution to present some central insights of recent historiography on the changing relationship that various Protestant and Catholic actors have to concepts, ideas and practices of masculinity. Werner draws here primarily on the comprehensive results that emerged from the research group in which she has been involved, Christian Manliness $-A$ Paradox of Modernity. ${ }^{68}$ For her, the emergence of a specifically Christian concept of 'manliness' in the $19^{\text {th }}$ century, and repeated debates on a (re-)masculinization of Christianity, should be seen as attempts by religious actors to respond to the challenges of (secular) modernity, with these attempts sometimes differing depending on denomination and nation. ${ }^{69}$ Felix Krämer also takes a historical perspective in his contribution, and examines such a debate on Christian masculinity in detail by investigating the interplay and interaction between concepts of moral leadership and 'whiteness', the rise of evangelical revivalist preachers, and media discourses in the political controversies that the US witnessed in the I970s and I980s. Krämer's work is an excellent example of how historical research can make theoretical reflections fruitful, since he demonstrates precisely how semantics of crisis could be harnessed in these conflicts in order to lend new social legitimacy to notions of hegemonic white, heterosexual and Christian masculinity. Whether it is possible today to speak in a fundamental way of a (re-)masculinization of the Christian religion is a question that the sociologist Friederike Benthaus-Apel investigates in her empirical investigation. She casts doubt on such a conclusion on the basis of the results of the research project Religion and Gender, 70 and points out instead that a higher level of religiosity among women can be attested for 20I2, too. Benthaus-Apel sees a possible explanation for the continuation of this gender gap in what is still a different pattern of religious socialization for boys and girls at home, a pattern that shapes the later religious behaviour of men and women.

68 The research association of European historians was active until 20I0, and was coordinated by the University of Lund. For the results, see Werner (ed.) $201 \mathrm{I}$.

69 On this, see also the findings of Blaschke 20II and Brown $201 \mathrm{I}$.

70 The project was carried out in 20I4/20I5 by the Comenius Institute in Münster and the Protestant University of Rhineland-Westphalia-Lippe under the direction of Friederike Benthaus-Apel. The aim of the project was among other things to clarify "the contribution of the social category of gender in processes of (religious) interpretation". See the project homepage: https://www.evh-bochum.de/abgeschlossene-projekte/articles/g ender-und-religion.html [Accessed: I6/04/20I8]. 
A detailed overview of the relationship between Islam and masculinity is provided by Miriam Kurz. Taking as her starting-point contemporary debates about the 'Muslim man', she warns in her socio-constructivist contribution against essentializing Muslim men as violent, sexualized, radical, etc., and instead calls for a more nuanced view, since "both Islam and masculinity are complex, plural, and dynamic phenomena" (I05). In brief, she painstakingly traces the gender-specific concepts provided by the Quran and the theological discourses of Islam, and how these have been taken up and interpreted by various Muslim (legal) schools. In the second part of her contribution, she contrasts the diversity of Islamic concepts of masculinity with current stereotypes of the 'Muslim man', and considers the popularity of these stereotypes in Western societies within the framework of theoretical considerations of a crisis of hegemonic masculinity. The crisis of Islamic masculinity itself then finds a voice in the contribution by Amanullah De Sondy, Senior Lecturer in Contemporary Islam in Cork, Ireland. ${ }^{7 \mathrm{I}} \mathrm{He}$ also refers to the diversity of concepts of masculinity present in the Quran and in the Islamic tradition, and pays particular attention to mapping out the contradictoriness and ambiguity of individual concepts. ${ }^{72}$ According to De Sondy, the Quran and the various Islamic schools of law have often been much more open to plurality and diversity in their interpretations than many Muslims and non-Muslims wish to admit today. Emphasizing this diversity again is "a powerful tool in combatting Islamophobia and hegemonic masculinity because both are based on rigid monoliths that in reality do not exist" (I45). 73

The section on the relationship between Judaism and masculinity begins with a bibliographical essay by the Jewish Talmud scholar Admiel Kosman. He emphasizes that, if we look back in history, then we can understand the (hegemonic) position of the 'Jewish man' in the community as well as in his own household only by referring to contemporary ideas of femininity and the role of the 'woman'. Kosman thus implicitly chooses an intersectional approach to understand the relationship between religion and masculinity, a relationship that he links to numerous examples from the Jewish tradition and literature. Drawing on the pioneering study by Daniel Boyarin that we have already mentioned, Kosman concludes that the prevailing ideal of Jewish masculinity was long characterized by erudition, softness, and empathy (and

${ }_{71}$ On this, see, in more detail, De Sondy $20 \mathrm{I} 4$.

72 On the ambiguity of Islam as a whole, see Bauer 20II.

73 At the conference in November 2016 that led to the contributions in this volume, the reflections on 'Islam and masculinity' were supplemented by a lecture by Andreas Ismael Mohr on Which is Worse: Zina or Liwat? Why, and For Whom? Concepts and Practices of Masculinities in 'Pre-Modern' Islam. We very much regret that we cannot include his reflections here. 
especially with regard to family members). 74 It was only as a result of Zionism that a change to a muscular and energetic image of men took place.75 A similar conclusion is drawn by Matthias Morgenstern, who in his chapter on the discourses of masculinity in rabbinical literature and talmudic culture investigates "what men (and women) are and what they are supposed to be" (I85). Based on a detailed examination of commandments in liturgical practice, as well as in everyday life, he traces this ideal of masculinity, and makes clear how it also had practical consequences for the daily lives of Jewish men and women, lives in which the latter managed the household and represented the family to the outside world. This resulted, according to Morgenstern, in Jewish women adapting much more easily than their husbands to the conditions of (Western) modernity. The chapter ends with an outlook on current and ongoing discussions on gender relations in Judaism as well as in Israeli society. The extent to which the ideas of masculinity in medieval Judaism were shaped by obedience to God is also illustrated by the historian Ruth Mazo Karras in her subtle reconstruction of the Christian and Jewish reception of the biblical story of David and Bathsheba. She traces the different lines of argumentation with which religious authors have sought to justify the behaviour of King David, who must be regarded as a male role model of the European Middle Ages. Despite evident differences between Judaism and Christianity, the goal of religious reasoning has ultimately always been to control "an unbounded male sexual desire that was a part of elite masculinities". However, according to Mazo Karras, history shows that in reality this "was never far from the surface" (2I4).

Serinity Young also deals in her introductory chapter on South Asian masculinities with the contradiction between ideals of masculinity and social reality. She takes up important aspects of the current theoretical debate on masculinity, and applies them to examples of Hindu and Buddhist traditions. For example, she discusses the different roles that are attributed to men as fathers and husbands, outlines the importance of the distinction between 'purity/pollution' in South Asian religious cultures, and addresses questions of instability and fluidity of masculinities. Young concludes with regard to hegemonic concepts of masculinity that "[the] conflict between rhetoric and reality in many cases produces a personal sense of inadequacy rather than of superiority" (238). How strongly ideas of male supremacy have always been

74 See Boyarin 1997.

75 This contrast is portrayed very vividly in, for example, Amos Oz's autobiographical novel A Tale of Love and Darkness (2002). To what extent this new image of masculinity was also connected with the goal of building an independent nation would be worth examining in more detail. For more on 'muscular Judaism', see the articles by Morgenstern, I85-200, and Kosman, I49-I83, in this volume. On masculinity and nation, see, for example, Nagel 2004 and Andersen/Wendt (eds) 2015. 
used in Buddhist traditions in India is illustrated by John Powers in his chapter on 'The Gendered Buddha'. He points out that - contrary to established (Western) perspectives - the emphasis on masculine (bodily) attributes has always played a crucial role in the stylization of Buddha by his followers. ${ }^{76}$ Powers interprets this process as part of a strategy to upgrade Buddhist beliefs and practices, so that they can compete with other religious offerings.77 Renate Syed deals with the question of which ideals of masculinity have been responsible for centuries for shaping Hindu religions on the Indian subcontinent. As well as mapping out the various ideals, she also traces the formative historical developments, and points out when she deals, for example, with older religious tradition in South India where boundaries shifted and dissolved. Syed concludes that, despite all changes "[the] general paradigms [of Hindu masculinities] defined by caste or class, age, stage of life and other markers remain in many cases the same" (276).

Björn Krondorfer, who has long studied the relationship between religion and masculinity, points at the end of the volume to past, present and future currents in 'critical men's studies in religion'. Besides providing a brief outline of previous work, he explores above all the question of why masculinity is consistently reproduced as hegemonic, and yet still often remains in general perception as an "unmarked"78 gender. According to Krondorfer, this phenomenon can also be observed precisely with regard to religion, where we have learned to speak since the Enlightenment about God's body and gender, while at the same time repeatedly losing sight of the question of the construction of masculinity. His plea is therefore to make masculinity a lasting and central theme in the study of religion, since it is "an absence that needs our attention, and that is true for all world religions that follow patriarchal traditions" (288).

\section{Conclusion}

If we read the contributions in this volume against the background of the theoretical reflections that we have made, then we can identify several fundamental conceptual as well as thematic gaps in current research on the relation-

76 In doing so, Powers deals more intensively than any other chapter in this volume with issues of the male body. His insights are largely based on his many years of research on the issue; see Powers 2009. On the relationship between masculinity and body, see also, for example, Butler I990; Reeser 20I0, 9I-II8; and, with reference to religion, the reflections in this volume of Krondorfer, 283-300.

77 The connection between ideals of masculinity and Hinduism is discussed, for example, in the essays in Chopra et al. (eds) 2004; Gupta 20II; and in the essay by Syed in this volume, $265-280$.

78 Reeser 20I0, 8. 
ship between religion and masculinity. Future research cannot of course tackle all the gaps at the same time and to the same extent. We will therefore conclude by reiterating the most important points that we consider to be of central importance for new substantive and theoretical perspectives on the relationship between religion and masculinity. The whole can be read as a draft for a kind of research matrix to help us in the future to create a reflected and thus grounded research design comprising different categories and aspects.

One of the central research perspectives in the coming years will remain the analysis of the multiply relational formation of men and masculinities. As we have already explained in detail, this will consider on the one hand the hetero- and homosocial dimension of relationships that men and masculinities have to women and femininities, and to other men. In a way, the bibliographical essay by Admiel Kosman on masculinities in Jewish religion and culture in this volume may serve as an example of such research. On the other hand, it will be increasingly necessary in the future to work out in detail the relationship between masculinity and socio-structural categories such as class and race, national and ethnic affiliation. For such an intersectional analysis, future research needs to maintain its focus on demonstrating the way in which religion is entangled with other categories of social reality that have significance in the constitution of different masculinities. This is made explicit in the present volume only in the overview of Islam and masculinity provided by Miriam Kurz, and by Felix Krämer, who demonstrates the close entanglements of race, politics and religion in the political culture of the US during the I970s and I980s. However, other contributions do suggest similar intersectional dimensions. For example, Matthias Morgenstern points to the socioeconomic (and political) consequences of the specifically feminine expression of Jewish-religious masculinity in the pre-modern period, while John Powers analyzes "[t]he creation of the literary figure "Buddha"" in economic terms "as part of a marketing strategy" (257).

But, contrary to such recent research approaches, the overwhelming majority of the contributions here continue to make theoretical use, either implicitly or explicitly, of Connell's concept of hegemonic masculinity, thereby confirming a continuing trend in masculinity studies as a whole. This is problematic both here and in Connell's work, since the concept itself is rarely discussed critically, and the validity of its premises and insights is rarely checked. Rather, scholars often simply and unquestioningly use hegemonic masculinity as the classic topos of their own research. However, future studies on the relationship between religion and masculinity would urgently require a critical approach to the concept - one that, for example, radically expands its theoretical foundations and includes, say, Bourdieu's concept of habitus, discourse theories as developed from the work of Michel Foucault, 
and Judith Butler's idea of performativity. Careful approaches to such a development can be seen in the present volume, for example, in the three contributions on concepts of masculinity in South Asia. This may possibly be related to the lower degree of hierarchical organization of the religious traditions there, to the limited canonization of sacred texts, and to a pronounced corporeality. If future research on the relationship between religion and masculinity succeeds in taking up the impulses provided by the concepts named above in a more decisive way than has hitherto been the case, then more complex research designs could finally attempt to examine critically and to develop further these theoretical approaches on the basis of empirical analyses.

Drawing on such a reflected theoretical integration, future research on the relationship between religion and masculinity should then turn increasingly to concrete case studies. In conceptualizing such case studies, we should pay particular attention to three aspects. First, the aspect of social practice needs to be given more attention than has hitherto been the case. In other words, we should pursue the question of how religious ideas, norms, and discourses have influenced (and still influence) the concrete (everyday) practices of masculinity, how they legitimize or delegitimize them, and how in turn the social practice of being a man influences religious traditions, organizations and actors. For example, in the section on South Asia in this volume, Hindu and Buddhist narratives are described and analyzed with a high level of literary competence from the perspective of religious studies. However, the question of how far these narratives have influenced and sustained the social practice of men both today and in the past is touched on only very briefly.

Second, future case studies will need to place the issues and questions under investigation into a global framework of transnational relations and inter-religious comparisons. It is especially the latter that has often been neglected, and this is the case in the contributions to this volume, too. We can only point to the chapter by Yvonne Maria Werner, who compares Catholics and Protestants from a historical perspective. Increasingly important in this context will be the relationship between masculinity, religion and migration, as Miriam Kurz points out in her chapter. Third, future studies on the subject will ultimately not be able to avoid addressing each specific historical contingency of religion, masculinity, and how they relate to each other. For, one thing has been made evident not only by the theoretical reflections of the last few decades, but also by all previous case studies: namely, that all aspects and themes to do with the connection between religion and masculinity prove from an academic perspective to be contingent and mutable, and not 'eternal', 'natural' or 'trans-temporal', as they are necessarily conceived to be in the internal perspective of the religions themselves. A precise historical location of their analyses will therefore prove fruitful for future research practice. For, 
both masculinity and religion are indeed "an elusive phenomenon (296), as Björn Krondorfer calls them at the end of this volume, since both they themselves and their relationship are subject to constant change.

\section{Bibliography}

Andersen, Pablo Dominguez / Wendt, Simon (eds) (2015): Masculinities and the Nation in the Modern World. Between Hegemony and Marginalization. Basingstoke: Palgrave Macmillan.

Asad, Talal (1993): Genealogies of Religion. Discipline and Reasons of Power in Christianity and Islam. Baltimore, MD: Johns Hopkins University Press.

Baader, Benjamin Maria / Gillerman, Sharon / Lerner, Paul (eds) (20I2): Jewish Masculinities. German Jews, Gender, and History. Bloomington, IN: Indiana University Press.

Barthes, Roland (1967): Elements of Semiology. New York, NY: Hill and Wang (orig. (1964): Éléments de Sémiologie. Paris: Editions du Seuil).

Bauer, Thomas (20II): Die Kultur der Ambiguität. Eine andere Geschichte des Islams. Frankfurt: Suhrkamp.

Bhabha, Homi K. (1994): The Location of Culture. New York, NY: Routledge.

Blaschke, Olaf (20II): The Unrecognized Piety of Men. Strategies and Success of the Re-Masculinization Campaign around I900. In: Werner, Yvonne Maria (ed.): Christian Masculinity. Men and Religion in Northern Europe in the I9th and 20th Centuries. Leuven: Leuven University Press, $2 \mathrm{I}-45$.

Bock, Gisela (1988): Geschichte, Frauengeschichte, Geschlechtergeschichte. In: Geschichte und Gesellschaft I4 (3), 364-39I.

Borutta, Manuel (20I4): Kulturkampf als Geschlechterkampf? Geschlecht als Grenze der Säkularisierung im I9. Jahrhundert. In: Stollberg-Rilinger, Barbara (ed.): "Als Mann und Frau schuf er sie". Religion und Geschlecht. Würzburg: Ergon, I09-I37.

Bosse, Hans / King, Vera (eds) (2000): Männlichkeitsentwürfe. Wandlungen und Widerstände im Geschlechterverhältnis. Frankfurt / New York, NY: Campus.

Boswell, John (1980): Christianity, Social Tolerance, and Homosexuality. Gay People in Western Europe from the Beginning of the Christian Era to the Fourteenth Century. Chicago, IL: The University of Chicago Press.

Bourdieu, Pierre (1990): The Logic of Practice. Stanford: Stanford University Press (orig. (1980): Les sens practique. Paris: Les Éditions de Minuit).

Bourdieu, Pierre (1998): La domination masculine. Paris: Editions du Seuil. 
Bourdieu, Pierre (200I): Masculine Dominance. Stanford: Stanford University Press.

Bourdieu, Pierre (2005): Die männliche Herrschaft. Frankfurt: Suhrkamp.

Boyarin, Daniel (1997): Unheroic Conduct. The Rise of Heterosexuality and the Invention of the Jewish Man. Berkeley, CA: University of California Press.

Brod, Harry (20II): The Construction of the Construction of Masculinities. In: Horlacher, Stefan (ed.): Constructions of Masculinity in British Literature. From the Middle Ages to the Present. New York, NY: Palgrave, I9-32.

Brod, Harry / Zevit, Shawn Israel (eds) (2010): Brother Keepers. New Perspectives on Jewish Masculinity. Harriman, TN: Men's Studies Press.

Brown, Callum G. (20II): Masculinity and Secularization in TwentiethCentury Britain. In: Werner, Yvonne Maria (ed.): Christian Masculinity. Men and Religion in Northern Europe in the 19th and 2oth Centuries. Leuven: Leuven University Press, 47-59.

Brunotte, Ulrike / Herrn, Rainer (eds) (2007): Männlichkeiten und Moderne. Geschlecht in den Wissenskulturen um I90o. Bielefeld: transcript.

Bublitz, Hannelore (2002): Judith Butler zur Einführung. Hamburg: Junius.

Buckel, Sonja / Fischer-Lescano, Andreas (eds) (2007): Hegemonie gepanzert mit Zwang. Zivilgesellschaft und Politik im Staatsverständnis Antonio Gramscis. Baden-Baden: Nomos.

Butler, Judith (1988): Performative Acts and Gender Constitution. An Essay in Phenomenology and Feminist Theory. In: Theatre Journal 40 (4), 519-53I.

Butler, Judith (1990): Gender Trouble. Feminism and the Subversion of Identity. New York, NY: Routledge.

Chopra, Radhika / Osella, Filippo / Osella, Caroline (eds) (2004): South Asian Masculinities. Context of Change, Sites of Continuity. Delhi: Women Unlimited.

Connell, Raewyn W. (1987): Gender and Power. Society, the Person and Sexual Politics. Stanford, CA: Stanford University Press 1987.

Connell, Raewyn W. (1995): Masculinities. Knowledge, Power and Social Change. Berkeley / Los Angeles, CA: University of California Press.

Connell, Raewyn W. (1999): Der gemachte Mann. Konstruktion und Krise von Männlichkeiten. Opladen: Leske + Budrich.

Connell, Raewyn W. (20I6): Masculinities in Global Perspective. Hegemony, Contestation, and Changing Structures of Power. In: Theory and Society 45 (4), 303-318. 
Connell, Raewyn W. / Hearn, Jeff / Kimmel, Michael (eds) (2004): Handbook of Studies on Men and Masculinities. Thousand Oaks, CA et al.: Sage Publications.

Creanga, Ovidiu (ed.) (2010): Men and Masculinity in the Hebrew Bible and Beyond. Sheffield: Sheffield Phoenix Press.

Cyba, Eva (20I0): Patriarchat. Wandel und Aktualität. In: Becker, Ruth / Kortendiek, Beate (eds): Handbuch Frauen- und Geschlechterforschung. Theorie, Methoden, Empirie. 3rd edition. Wiesbaden: VS Verlag für Sozialwissenschaften, I7-22.

De Groot, Joanna / Sue, Morgan (2013): Beyond the 'Religious Turn'? Past, Present and Future Perspectives in Gender History. In: Gender and History 25 (3), 395-422.

De Sondy, Amanullah (20I4): The Crisis of Islamic Masculinities. London / New York, NY: Bloomsbury Academic.

De Vries, Hent (ed.) (2008): Religion. Beyond a Concept. New York, NY: Fordham University Press.

Despland, Michel / Vallée, Gérard (eds) (1992): Religion in History. The Word, the Idea, the Reality. Waterloo, ON: Wilfrid Laurier University Press.

Dinges, Martin (ed.) (1998): Hausväter, Priester, Kastraten. Zur Konstruktion von Männlichkeit in Spätmittelalter und Früher Neuzeit. Göttingen: Vandenhoeck \& Ruprecht.

Dinges, Martin (ed.) (2005): Männer - Macht - Körper. Hegemoniale Männlichkeiten vom Mittelalter bis heute. Frankfurt / New York, NY: Campus.

Douglas, Mary, (1966): Purity and Danger. An Analysis of the Concepts of Pollution and Taboo. London: Routledge and Kegan Paul.

Dubuisson, Daniel (2003): The Western Construction of Religion. Myths, Knowledge, and Ideology. Baltimore: Johns Hopkins University Press

Durkheim, Émile (2008): Les formes élémentaires de la vie religieuse. Le système totémique en Australie. Paris: PUF (orig. 19I2).

Engler, Steffani (20I0): Habitus und sozialer Raum. Zur Nutzung der Konzepte Pierre Bourdieus in der Frauen- und Geschlechterforschung. In: Becker, Ruth / Kortendiek, Beate (eds): Handbuch Frauen- und Geschlechterforschung. Theorie, Methoden, Empirie. 3rd edition. Wiesbaden: VS Verlag für Sozialwissenschaften, 257-268.

Eribon, Didier (20II): Michel Foucault (I926-I984). 3rd edition. Paris: Flammarion. 
Feil, Ernst (1986-2007): Religio. Die Geschichte eines neuzeitlichen Grundbegriffs. 4 volumes. Göttingen: Vandenhoeck \& Rupprecht.

Feil, Ernst (ed.) (2000): Streitfall 'Religion'. Diskussionen zur Bestimmung und Abgrenzung des Religionsbegriffs. Münster: LIT.

Fitzgerald, Timothy (2000): The Ideology of Religious Studies. New York, NY / Oxford: Oxford University Press.

Flood, Michael / Kegan Gardiner, Judith / Pease, Bob / Pringle, Keith (eds) (2007): International Encyclopaedia of Men and Masculinities. New York, NY: Routledge.

Foucault, Michel (1966): Les mots et les choses: Une archéologie des sciences humaines. Paris: Gallimard.

Foucault, Michel (1969), L'archéologie du savoir. Paris: Gallimard.

Foucault, Michel (1976-1984): Histoire de la sexualité. 3 volumes. Paris: Gallimard.

Foucault, Michel (2018): Les aveux de la chair. Paris: Gallimard.

Fowler, Bridget (2007): Pierre Bourdieus Die männliche Herrschaft lesen. Anmerkungen zu einer intersektionellen Analyse von Geschlecht, Kultur und Klasse. In: Bock, Ulla / Dölling, Irene / Krais, Beate (eds): Prekäre Transformationen. Pierre Bourdieus Soziologie der Praxis und ihre Herausforderungen für die Frauen- und Geschlechterforschung. Göttingen: Wallstein, I4I-I75.

Giddens, Anthony (1984): The Constitution of Society. Outline of the Theory of Structuration. Berkeley / Los Angeles, CA: University of California Press.

Gramsci, Antonio (1934): Quaderno 25 (XXIII). In: Antonio Gramsci. Quaderni del carcere. Edited by Valentino Gerratana. Turin: Einaudi, 2279-2294.

Gupta, Charu (20II): Anxious Hindu Masculinities in Colonial North India. Shuddhi and Sangathan Movements. In: Cross Currents 6I (4), 44I-454.

Hearn, Jeff (20II): Neglected Intersectionalities in Studying Men. Age(ing), Virtuality, Transnationality. In: Lutz, Helma / Herrera Vivar, Maria Teresa / Supik, Linda (eds): Framing Intersectionality. Debates on a Multi-Faceted Concept in Gender Studies. Farnham / Burlington: Routledge, 89-I04.

Heitzmann, Daniela (2015): Männliche Herrschaft. In: Gender Glossar / Gender Glossary. URL: http://gender-glossar.de [Accessed: 07/03/20I8].

Heller, Birgit (2002): Gender und Religion. In: Figl, Johann (ed.): Handbuch Religionswissenschaft. Göttingen: Vandenhoeck \& Ruprecht, 758-769. 
Heller, Birgit (20I0): Religionen. Geschlecht und Religion - Revision des homo religosus. In: Becker, Ruth / Kortendiek, Beate (eds): Handbuch Frauen- und Geschlechterforschung. Theorie, Methoden, Empirie. 3rd edition. Wiesbaden: VS Verlag für Sozialwissenschaften, 713-718.

Hermann, Adrian (2015): Unterscheidungen der Religionen. Analysen zum globalem Religionsdiskurs und dem Problem der Differenzierung von 'Religion' in buddhistischen Kontexten des 19. und frühen 20. Jahrhunderts. Göttingen: Vandenhoeck \& Ruprecht.

Hock, Klaus (2002): Einführung in die Religionswissenschaft. Darmstadt: Wissenschaftliche Buchgesellschaft.

Höpflinger, Anna-Katharina / Jeffers, Ann / Pezzoli-Olgiati, Daria (eds) (2008): Handbuch Gender und Religion. Göttingen: Vandenhoeck \& Ruprecht.

Horlacher, Stefan / Jansen, Bettina / Schwanebeck, Wieland (eds) (20I6): Männlichkeit. Ein interdisziplinäres Handbuch. Stuttgart: J.B. Metzler.

Jäger, Ulle / König, Tomke / Maihofer, Andrea (2012): Pierre Bourdieu. Die Theorie männlicher Herrschaft als Schlussstein seiner Gesellschaftstheorie. In: Kahlert, Heike / Weinbach, Christine (eds): Zeitgenössische Gesellschaftstheorien und Genderforschung. Einladung zum Dialog. Wiesbaden: VS Verlag für Sozialwissenschaften, 15-36.

Keller, Reiner (2004): Diskursforschung. Eine Einführung für SozialwissenschaftlerInnen. Wiesbaden: Springer VS.

Kimmel, Michael (1987a): Changing Men. New Directions in the Study of Men and Masculinity. Newbury Park, CA: Sage.

Kimmel, Michael (1987b): The Contemporary 'Crisis' of Masculinity in Historical Perspective. In: Brod, Harry (ed.): The Making of Masculinities. The New Men's Studies. Boston, MA: Allen and Unwin, I2I-I53.

Kimmel, Michael (1996): Manhood in America. A Cultural History. New York, NY: Free Press.

King, Ursula King (ed.) (1995): Religion and Gender. Oxford: Basil Blackwell.

Kippenberg, Hans / Stuckrad, Kocku von (eds) (2003): Einführung in die Religionswissenschaft. 2 volumes. München: C.H. Beck.

Klinken, Adriaan van (2013): Transforming Masculinities in African Christianity. Gender Controversies in Times of AIDS. Farnham / Burlington: Ashgate.

Krais, Beate (20II): Die männliche Herrschaft. Ein somatisiertes Herrschaftsverhältnis. In: Österreichische Zeitschrift für Soziologie 36 (4), 33-50. 
Krämer, Felix / Mackert, Nina (20I0): Wenn Subjekte die Krise bekommen. Hegemonie, Performanz und Wandel am Beispiel einer Geschichte moderner Männlichkeit. In: Landwehr, Achim (ed.): Diskursiver Wandel. Wiesbaden: Springer VS, 265-279.

Krondorfer, Björn (2009): Introduction. In: Id. (ed.): Men and Masculinities in Christianity and Judaism. A Critical Reader. London: SCM Press, xixxi.

Krondorfer, Björn (20I6): Religion und Theologie. In: Horlacher, Stefan / Jansen, Bettina / Schwanebeck, Wieland (eds): Männlichkeit. Ein interdisziplinäres Handbuch. Stuttgart: J.B. Metzler, 204-2I8.

Krondorfer, Björn / Culbertson, Philip (2005): Men's Studies in Religion. In: Jones, Lindsay / Eliade, Mircea / Adams, Charles J. (eds): Encyclopaedia of Religion. Volume 9. 2nd edition. Detroit, MI / New York, NY: Macmillan, 586I-5865.

Krondorfer, Björn / Hunt, Stephen (20I2): Introduction. Religion and Masculinities - Continuities and Change. In: Religion and Gender 2 (2), I94-206.

Kucklick, Christoph (2008): Das unmoralische Geschlecht. Zur Geburt der Negativen Andrologie. Frankfurt: Suhrkamp.

Kugle, Scott (2010): Homosexuality in Islam. Critical Reflection on Gay, Lesbian, and Transgender Muslims. Oxford: Oneworld Publications.

Kugle, Scott / Hunt Stephen (2012): Masculinity, Homosexuality and the Defence of Islam. A Case Study of Yusuf al-Qaradawi's Media Fatwa. In: Religion and Gender 2 (2), 254-279.

Landwehr, Achim (2008): Historische Diskursanalyse. Frankfurt / New York, NY: Campus.

Lenz, Ilse (20I0): Intersektionalität. Zum Wechselverhältnis von Geschlecht und sozialer Ungleichheit In: Becker, Ruth / Kortendiek, Beate (eds): Handbuch Frauen- und Geschlechterforschung. Theorie, Methoden, Empirie. 3rd edition. Wiesbaden: VS Verlag für Sozialwissenschaften, I58-165.

Martschukat, Jürgen / Stieglitz, Olaf (2008): Geschichte der Männlichkeiten. Frankfurt / New York, NY: Campus.

Masuzawa, Tomoko (2005): The Invention of World Religion. Or, How European Universalism Was Preserved in the Language of Pluralism. Chicago. Chicago University Press.

McCutcheon, Russell T. (1997): Manufacturing Religion. The Discourse on Sui Generis Religion and the Politics of Nostalgia. New York, NY / Oxford: Oxford University Press. 
Meuser, Michael (2010): Geschlecht und Männlichkeit. Soziologische Theorie und kulturelle Deutungsmuster. 3rd edition. Opladen: Leske + Budrich.

Meuser, Michael (20I6): Soziologie. In: Horlacher, Stefan / Jansen, Bettina / Schwanebeck, Wieland (eds): Männlichkeit. Ein interdisziplinäres Handbuch. Stuttgart: J.B. Metzler, 218-236.

Mosse, George L. (1996): The Image of Man. The Creation of Modern Masculinity. New York, NY / Oxford: Oxford University Press.

Nagel, Joane: Nation. In: Connell, Raewyn W. / Hearn, Jeff / Kimmel, Michael (eds) (2004): Handbook of Studies on Men and Masculinities. Thousand Oaks, CA et al.: Sage Publications, 397-413.

Opitz-Belakhal, Claudia / Hämmerle, Christa (eds) (2008): Krise(n) der Männlichkeit (L'Homme. Europäische Zeitschrift für Feministische Geschichtswissenschaft I9 (2)). Köln et al.: Böhlau.

Ouzgane, Lahoucine (ed.) (2006): Islamic Masculinities. London: Zed Books.

Pasture, Patrick / Art, Jan / Buerman, Thomas (eds) (2012): Gender and Christianity in Modern Europe. Beyond the Feminization Thesis. Leuven: Leuven University Press.

Pollack, Detlef (20I8): Probleme der Definition von Religion. In: Pollack, Detlef / Krech, Volkhard / Müller, Olaf / Hero, Markus (eds) (20I8): Handbuch Religionssoziologie. Springer VS: Wiesbaden, I7-50.

Pollack, Detlef / Rosta, Gergely (2017): Religion and Modernity. An International Comparison. Oxford: Oxford University Press 2017 (orig. (2015): Religion in der Moderne. Ein internationaler Vergleich (Religion und Moderne I). Frankfurt / New York, NY: Campus).

Powers, John (2009): A Bull of a Man. Images of Masculinity, Sex, and the Body in Indian Buddhism. Cambridge: Harvard University Press.

Purtschert, Patricia (2003): Feministischer Schauplatz umkämpfter Bedeutungen. Zur deutschsprachigen Rezeption von Judith Butlers "Gender Trouble". In: Widerspruch 44, I47-I58.

Reeser, Todd W. (2010): Masculinities in Theory. Malden, MA / Oxford: Wiley-Blackwell.

Reeser, Todd W. (20I6): Englischsprachige Männlichkeitsforschung. In: Horlacher, Stefan / Jansen, Bettina / Schwanebeck, Wieland (eds): Männlichkeit. Ein interdisziplinäres Handbuch. Stuttgart: J.B. Metzler, 26-42.

Religion, Transformation and Gender (2017). Volume of the Interdisciplinary Journal for Religion and Transformation 5. URL: http://www.v-r.de/de/reli gion_transformation_and_gender/c-3I66 [Accessed: oI/03/20I8]. 
Roberts, Mary Louise (20I6): Beyond 'Crisis' in Understanding Gender Transformation. In: Gender and History 28 (2), 358-366.

Robinson, Sally (2007): Crisis in Masculinity. In: Flood, Michael / Kegan Gardiner, Judith / Pease, Bob / Pringle, Keith (eds): International Encyclopaedia of Men and Masculinities. New York, NY: Routledge, 90/9I.

Sarasin, Philipp (2003): Geschichtswissenschaft und Diskursanalyse. Frankfurt: Suhrkamp.

Sarasin, Philipp (2013): Michel Foucault zur Einführung. 5th edition. Hamburg: Junius.

Schuhen, Gregor (20I4): Crisis? What Crisis? Männlichkeiten um I900. In: Id. (ed.): Der verfasste Mann. Männlichkeiten in der Literatur und Kultur um 1900. Bielefeld: transcript, 7-I8.

Scott, Joan W. (1986): Gender. A Useful Category of Historical Analysis. In: American Historical Review 9I (5), I053-I075.

Soucy, Alexander (1999): Masculinities and Buddhist Symbolism in Vietnam. In: Biber, Katherine / Sear, Tom / Trudinger, Dave (eds): Playing the Man. New Approaches to Masculinity. Sydney: Pluto Press, I23-I34.

Stollberg-Rilinger, Barbara (ed.) (20I4): "Als Mann und Frau schuf er sie". Religion und Geschlecht. Würzburg: Ergon.

Tosh, John (1994): What Should Historians Do with Masculinity? Reflections on Nineteenth-Century Britain. In: History Workshop 38, I79-202.

Tosh, John (I999): A Man's Place. Masculinity and the Middle-Class Home in Victorian England. New Haven / London: Yale University Press.

Walz, Heike (2008): Blinde Flecken. Warum es theologische Geschlechterdialoge querbeet braucht. In: Id. / Plüss, David (eds): Theologie und Geschlecht. Dialoge querbeet. Berlin: LIT, I0-36.

Werner, Yvonne Maria (ed.) (20II): Christian Masculinity. Men and Religion in Northern Europe in the I9th and 20th Centuries. Leuven: Leuven University Press.

Willems, Ulrich / Reuter, Astrid / Gerster, Daniel (eds) (20I6): Ordnungen religiöser Pluralität. Wirklichkeit - Wahrnehmung - Gestaltung (Religion und Moderne 3). Frankfurt / New York, NY: Campus Verlag.

Wohlrab-Sahr, Monika / Rosenstock, Julika (2000): Religion - soziale Ordnung - Geschlechterordnung. Zur Bedeutung der Unterscheidung von Reinheit und Unreinheit im religiösen Kontext. In: Lukatis, Ingrid / Sommer, Regina / Wolff, Christof (eds): Religion und Geschlechterverhältnis. Opladen: Leske+Budrich, 279-298. 